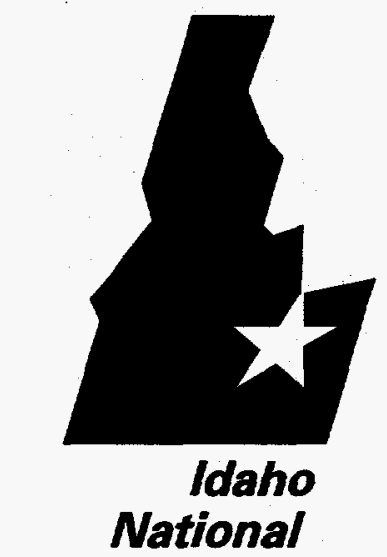

Engineering Laboratory
INEL-95/0576

November 1995
Idaho National Engineering Laboratory Materials in Inventory Natural and Enriched Uranium Management and Storage Costs 


\section{DISCLAMMER}

Portions of this document may be illegible in electronic image products. Images are produced from the best available original document. 
This report was prepared as an account of work sponsored by an agency of the United States Government. Neither the United States Government nor any agency thereof, nor any of their employees, makes any warranty, express or implied, or assumes any legal liability or responsibility for the accuracy, completeness, or usefulness of any information, apparatus, product, or process disclosed, or represents that its use would not infringe privately owned rights. Reference herein to any specific commercial product, process, or service by trade name, trademark, manufacturer, or otherwise does not necessarily constitute or imply its endorsement, recommendation, or favoring by the United States Government or any agency thereof. The views and opinions of authors expressed herein do not necessarily state or reflect those of the United States Government or any agency thereof.

\title{
Idaho National Engineering Laboratory Materials in Inventory Natural and Enriched Uranium Management and Storage Costs
}

\author{
R. L. Nebeker
}

Published November 1995

\section{Idaho National Engineering Laboratory Lockheed Idaho Technologies Company Idaho Falls, Idaho 83415}

Prepared for the

U.S. Department of Energy

Assistant Secretary for Environment Management

Under DOE Idaho Operations Office

Contract DE-AC07-94ID13223

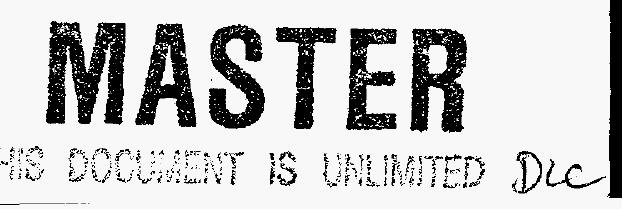





\section{CONTENTS}

ACRONYMNS $\ldots \ldots \ldots \ldots \ldots \ldots \ldots \ldots \ldots \ldots \ldots \ldots \ldots \ldots \ldots \ldots \ldots \ldots \ldots \ldots \ldots \ldots$

INTRODUCTION $\ldots \ldots \ldots \ldots \ldots \ldots \ldots \ldots \ldots \ldots \ldots \ldots \ldots \ldots \ldots \ldots \ldots \ldots$

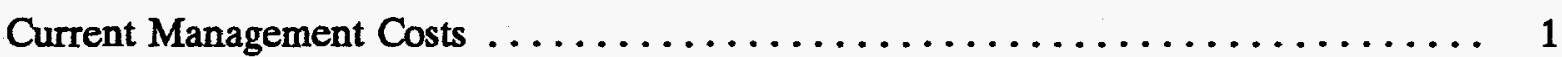

Current Inventory and Current Management Practices .............. 1

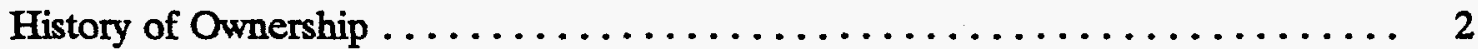

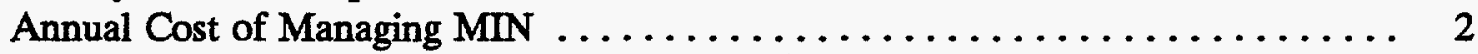

One-Time and Recurring Capital Costs $\ldots \ldots \ldots \ldots \ldots \ldots \ldots \ldots \ldots \ldots \ldots$

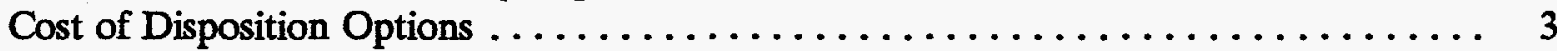

Cost to implement Potential Disposition Options $\ldots \ldots \ldots \ldots \ldots \ldots \ldots \ldots \ldots$

Revenue From Sale of $\mathrm{MIN} \ldots \ldots \ldots \ldots \ldots \ldots \ldots \ldots \ldots \ldots \ldots \ldots$

Savings Associated with Managing Decreased Volumes of MIN $\ldots \ldots \ldots \ldots \ldots$

Savings Associated with Consolidating Material $\ldots \ldots \ldots \ldots \ldots \ldots \ldots \ldots \ldots \ldots$

Determine Cost of Addressing Potential Vulnerabilities $\ldots \ldots \ldots \ldots \ldots \ldots \ldots \ldots$

\section{TABLES}

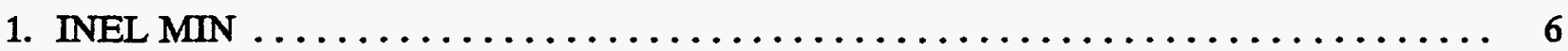

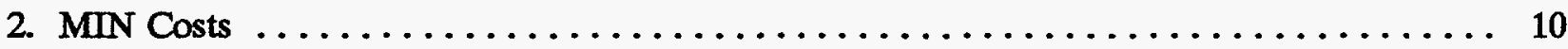

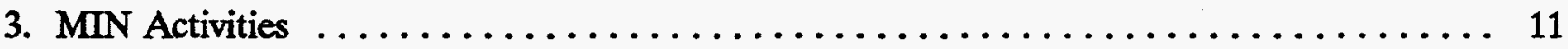

4. Disposition Activities $\ldots \ldots \ldots \ldots \ldots \ldots \ldots \ldots \ldots \ldots \ldots \ldots \ldots \ldots \ldots \ldots \ldots \ldots \ldots \ldots \ldots \ldots \ldots, 12$

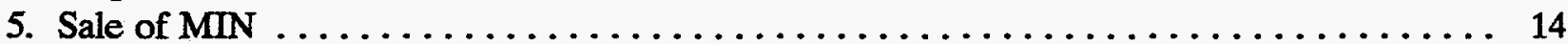

6. Cost Reductions ........................................ 15

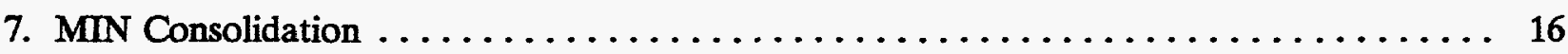

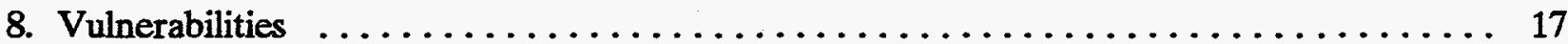




\section{ACRONYMS}

ADS

ANL

ARMF

ATR

B\&W

CPP

DOE

DP

EM

ER

ETR

GETR

IFSF

INEL

LANL

MIN

NBS

NE

NMIS

NR

ORNL

PBF
Activity Data Sheet

Argonne National Laboratory

Advanced Reactivity Measurement Facility

Advanced Test Reactor

Babcock and Wilcox

Chemical Processing Plant

Department of Energy

Defense Programs

Environmental Management

Environmental Restoration

Engineering Test Reactor

General Electric Test Reactor

Irradiated Fuel Storage Facility

Idaho National Engineering Laboratory

Los Alamos National Laboratory

Materials In Inventory

National Bureau of Standards

Nuclear Energy

Nuclear Materials Inspection and Storage

Naval Reactors

Oak Ridge National Laboratory

Power Burst Facility 
PWR

Pressurized Water Reactor

RW

Office of Civilian Radioactive Waste Management

TRA

Test Reactor Area

UA1

Uranium Aluminide 


\section{INTRODUCTION}

On July 13, 1994, the Office of Environmental Management (EM) was requested to develop a planning process that would result in management policies for dealing with nuclear materials in inventory. In response to this request, EM launched the Materials In Inventory (MIN) Initiative. A Headquarters Working Group was established to develop the broad policy framework for developing MIN management policies. MIN activities cover essentially all nuclear materials within the DOE complex, including such items as spent nuclear fuel, depleted uranium, plutonium, natural and enriched uranium, and other materials.

In August 1995, a report discussing the natural and enriched uranium portion of the MIN Initiative for the Idaho National Engineering Laboratory (INEL) was published. That report, "Idaho National Engineering Laboratory Materials-in-Inventory, Natural and Enriched Uranium ${ }^{1}{ }^{1}$ identified MIN under the control of Lockheed Idaho Technologies Company at the INEL. Later, additional information related to the costs associated with the storage of MIN materials was requested to supplement this report.

This report provides the cost information for storing, disposing, or consolidating the natural and enriched uranium portion of the MIN materials at the INEL. The information consists of eight specific tables which detail present management costs and estimated costs of future activities.

\section{Current Management Costs}

\section{Current Inventory and Current Management Practices}

Natural and enriched uranium materials which are managed by Lockheed Idaho Technologies Company are shown in Table 1 (all tables appear following the body of the report). These materials have been identified previously in Reference 1. Where the information is available, the containment method, in terms of the primary container, is shown and the material is described in terms of its physical description or matrix. The material in Table 1 is not classified as spent nuclear fuel because it has either been generated from past fuel processing activities, is material that was planned to be used in reactors in the future, or consists of samples or other miscellaneous material. Most of the material is unirradiated, although some of it may have been irradiated slightly as shown in the table. A few of the items may be slightly contaminated, also as noted. The quantity of material, in terms of kilograms of uranium, is also shown in the table. The majority of the material listed in Table 1 is stored in either the Unirradiated Fuel Storage Facility (CPP-651), the Nuclear Material Inspection and Storage Building (NMIS, TRA-621), and, to a lessor extent, the Irradiated Fuel Storage Facility (IFSF, CPP-603). These facilities and the current management practices related to their operation have been described in Reference 1 . The remainder of the material is in other INEL facilities or in off-site facilities under contract with the INEL.

1. Lockheed Idaho Technologies Company, Idaho National Engineering Laboratory Materials-inInventory Natural and Enriched Uranium, Report INEL-95/0308, (August 1995) 


\section{History of Ownership}

Much of the INEL funding presently comes from the DOE-EM organization. Other DOE organizations, including Defense Programs (DP), Nuclear Engineering (NE), Naval Reactors (NR), Environmental Restoration (ER), the Office of Civilian Radioactive Waste Management (RW) and occasionally others have funded and continue to fund other activities at the INEL. Most of the enriched and depleted uranium covered by this report and presently stored in CPP-651 and TRA-621 were recovered for or used by DP. Some of the material stored in TRA-621 [Engineering Test Reactor (ETR)/General Electric Test Reactor (GETR), Advanced Reactivity Measurement Facility (ARMF), etc.] was intended for use in test reactors and is owned by NE.

This report lists only those materials managed by the Department of Energy Idaho Operations Office (DOE-ID). The Argonne National Laboratory-West (ANL-W) area, which is also located at the INEL but which is not managed by DOE-ID, is not included in this report nor is other material at the INEL which is controlled by other off-site DOE organizations.

\section{Annual Cost of Managing MIN}

The annual cost of managing the INEL natural and enriched MIN is shown in Table 2. Since the majority of the MIN covered by this report is located at two INEL facilities, the operation of these facilities accounts for the majority of the costs associated with the MIN. These facilities are the Unirradiated Fuel Storage Facility at the Idaho Chemical Processing Plant (CPP-651) and the NMIS Facility at the Test Reactor Area (TRA-621). Some MIN also is stored at the ICPP IFSF where it is awaiting shipment to another location, and minor amounts are retained at other locations where it typically is used for testing or research applications. Costs for the present storage of MIN for CPP-651 and TRA-621 were obtained from the budget activity data sheets (ADS) where these costs are identified. The cost of storing MIN at the IFSF is based on the calculated cost of storage for each storage location. Costs at other storage facilities are minor because of the minor quantities stored and their association with other programs. Annual costs consist of facility operation, safeguard activities, security, and related activities. Costs for special activities, such as inventories, are not included.

It is difficult to summarize costs in a table format since the costs vary with time and the activities anticipated or being conducted. Also, in a period of intense budget restrictions, it becomes necessary to postpone activities which are thought to be useful and cost effective because the funding for the activities simply is not available. The costs for the facilities shown in Table 2 are therefore minimal operating costs based on past or expected future budgets. The costs for CPP-651 include basic costs for surveillance and maintenance, which are required regardless of the activities being conducted at the facility. They are incurred even if no fuels are moved into or out of the facility. These costs typically include items such as operations surveillance, instrument calibrations, inventories, safety document preparation, general maintenance, preventive maintenance checks, and alarm checks. These activities are required regardless of whether material movements are occurring within the facility.

Costs for the TRA-621 facility also are the minimum costs for operation of the facility and include items such as radiation control support, accountability, building checks, custodial service, 
security checks, and similar items. Costs for management of materials used in experimental programs are typically minor and are covered by the program that uses them.

Costs for the IFSF include only the storage costs associated with MIN storage in an operating fuel storage facility.

\section{One-Time and Recurring Capital Costs}

The data call requested that one-time costs be included in Table 3. Because of the extreme shortage of funds presently in force throughout the DOE complex, no major upgrades or one-time funding requirements pertaining directly to $\mathrm{MIN}$ have been identified that are expected to have funding for completion. However, some funding has been provided to change the security profile at specific ICPP facilities, including CPP-651, and these activities will indirectly affect the storage of $\mathrm{MWN}$.

\section{Cost of Disposition Options}

\section{Cost to implement Potential Disposition Options}

Some of the materials shown previously in Table 1 have been identified for dispositioning to other locations. The dispositioning options are shown in Table 4 for the materials which have been identified as eligible for dispositioning to other locations. The weight of uranium in each batch of material also is shown along with the required activities and, where available, the costs of implementing the activities. Shipment of material to other sites is dependent on the ability of that site to accept the material and on the availability of funds to pay for the transfer. In many cases, neither the funding nor the permission to ship is presently available.

Unofficial cost estimates are available only for the major materials selected for transfer. These cost estimates are in some cases several years old and are being updated. Some estimates are recognized as likely being low because of uncertainties regarding the availability of shipping and storage containers as well as other uncertainties such as the time and labor required to prepare a shipment. Various considerations may limit the time that workers can spend in certain areas, thus limiting the productive time available for preparing materials for shipment.

The PARKA and LANL estimates include the cost of obtaining the $6 \mathrm{M}$ drums anticipated to be used for shipping the material to Oak Ridge National Laboratory (ORNL). These drums (110 gal) cost approximately $\$ 1100$ each. About 195 drums will be required for the Los Alamos National Laboratory (LANL) shipments and 136 drums will be needed to ship PARKA material. Costs are also included for the return of the drums. Labor costs are extremely dependent on the time required to prepare the shipment, which may be longer than anticipated in the original estimates. The costs in Table 4 therefore are the minimal shipping costs based on extremely preliminary data.

Costs for shipping the ETR and GETR materials include the costs of purchasing the shipping containers, packaging the fuel, paying for the shipment and the return of the containers, and support for project management and safeguards and security. The costs are dependent on 
whether new $6 \mathrm{M}$ drums are needed or if the ETR shipping containers are acceptable. ETR shipping containers are used in the Table 4 costs.

Cost estimates for transfers of other, smaller quantities of materials are not available. The costs shown in Table 4 are essentially ratioed from the LANL costs on the basis of the weight of material to be shipped and costs for shipping and returning the drums, and disregard the economies of scale derived from the large number of containers being shipped in the LANL case. These costs are therefore less firm than the other reported costs, and are probably too low.

\section{Revenue From Sale of MIN}

Table 5 requests information on revenue from the sale of $\mathrm{MWN}$. No sales of $\mathrm{MIN}$ have been identified at the INEL for the material covered by this report.

\section{Savings Associated with Managing Decreased Volumes of MIN}

Since the majority of the MIN at the INEL is stored in major facilities at the site, there is no significant decrease in costs if part of the inventory is disposed. Unless an entire facility is emptied so the facility can be totally shut down, the costs to operate and manage the facilities remain. A slight decrease in cost could conceivably be realized, but there is no firm data showing cost savings. The activities presently included in the operating costs, i.e., preventive maintenance, custodial services, radioactive contamination control, instrument and alarm calibration and maintenance, and similar activities that continue regardless of the quantity of material in storage. Only if the storage facility is completely emptied do some of these costs no longer apply and, even in that case, some costs remain unless the facility is completely surplused. Consequently, the savings associated with managing decreased volumes of MIN, shown in Table 6, indicate no reductions in cost until the entire inventory is removed. Even in this case, some costs would remain in maintaining the empty facility or in preparing the facility for decommissioning.

\section{Savings Associated with Consolidating Material}

As stated in the previous section, cost savings can only be effected through the removal of all material from a major facility. Consolidating material in one, rather than two, major facilities could result in some cost savings. In 1994, a task team was formed to evaluate the consolidation of TRA and ICPP special nuclear materials. The team determined that savings would accrue if the material presently stored in TRA-621 were to be transferred to CPP-651, but that the cost of moving the material would also be relatively high. ${ }^{2}$

Although initial costs (estimated to be about $\$ 1.4$ million at the time of the team's evaluation) would be incurred to transfer and store the material in CPP-651, savings would accrue over the following years, predominantly because of a reduction in the personnel needed for operations, safeguards, and physical security. A decrease of over 11 full-time employees was estimated to be possible if this change occurred. A net present value (NPV) of over $\$ 4.6$ million

2. Task Team Report, Consolidation of TRA and ICPP Special Nuclear Materials in CPP-651, (February 1994). 
in savings was calculated over the next 20 years for the consolidation case. These costs and savings are shown in Table 7. Presently, because of plans to eventually dispose of much of the material to Y-12 and because of the difficulty in obtaining funding for the initial cost of transferring the material, the move to CPP-651 is not anticipated. No studies are available regarding the savings that could occur from consolidating the MIN at fewer DOE sites; however, the present plans are to move much of the existing INEL material to Y-12 or other locations where it may be effectively recycled. Moving all INEL MIN to another site for consolidation is not considered practical considering the large quantity of MIN presently located at the INEL, the uncertainty in the DOE disposition plans, and the present condition of the CPP-651 facility, which is one of the most modern security storage areas in the DOE complex.

\section{Determine Cost of Addressing Potential Vulnerabilities}

Table 8 requests information related to reducing and correcting vulnerabilities at the site. The only vulnerability identified at the INEL for MIN material involves the PARKA fuel which is presently stored in CPP-603 IFSF. This fuel is stored in cardboard tubes, and concerns have been raised concerning the fire hazard of storing the material in these containers. The IFSF electrical utilities had earlier been identified as less than adequate. During an extended downtime, elevated temperatures of the materials could have potentially occurred because of the decay heat from the spent nuclear fuel inventory in the proximity of the cardboard tubes, thus creating a fire hazard. The IFSF electrical utilities have been upgraded to resolve this vulnerability. It is intended that the PARKA fuel be sent to Y-12, and the cost for this transfer is shown as a one-time cost on Table 8. This is the same cost as that shown previously in Table 4 for dispositioning of that material, and the same comments concerning the appropriateness of the cost estimate apply in Table 8. 


\begin{tabular}{|c|c|c|c|c|c|c|}
\hline Material (Type) . & $\begin{array}{l}\text { Facility/Building } \\
\text { Where } \\
\text { Stored/Managed }\end{array}$ & $\begin{array}{l}\text { Stored/Managed } \\
\text { Inside or Outside? }\end{array}$ & $\begin{array}{l}\text { Containment } \\
\text { Method }\end{array}$ & Phase/Matrix & $\begin{array}{l}\text { Rad. } \\
\text { Contaminated } \\
\text { (Yes/No) }\end{array}$ & $\begin{array}{l}\text { Quantity in } \\
\text { Inventory (Kgs) }\end{array}$ \\
\hline & & & & & & \\
\hline PARKA Rods & IFSF, CPP-603 & Inside & Vaults/Tubes & Graphite & Slightly & 147.976 \\
\hline UO3 Custom Product & CPP-651 & Inside & Cans & Powder & No & 25.155 \\
\hline Custom Process Samples & CPP-651 & Inside & Drums & Powder & No & 1.583 \\
\hline Fluorinel Scrap & CPP-651 & Inside & Drums/Cans, etc. & U-Zr Metal & No & 179.272 \\
\hline UO3 Samples & CPP-651 & Inside & Cabinet & Powder & No & 0.094 \\
\hline Fermi Pin & CPP-627 & Inside & Drum & UO2 Solid & Yes & 0.132 \\
\hline Custom Dissolver Solids & CPP-627 & Inside & Drum & Solid & Yes & 0.262 \\
\hline Tory-1I-A I & CPP-627 & Inside & Drum & Solid & Yes & 0.116 \\
\hline Metal Pellets & CPP-602 & Inside & Cabinet & Pellets & NA & 0.742 \\
\hline SPERT WAPD & CPP-637 & Inside & Cabinet & Solid & No & 0.17 \\
\hline Fluorinel Scrap & CPP-637 & Inside & Cabinet & U-Zr Metal & No & 0.075 \\
\hline Metal Standard Brick & CPP-651 & Inside & Drum & Solid & Yes & 0.831 \\
\hline ANL-W Scrap & CPP-651 & Inside & Drums, Cans & Vycor Glass, misc & No & 6.912 \\
\hline UO3 Product & CPP-651 & Inside & Cans & Powder & No & $1,343.62$ \\
\hline UO3 Product & CPP-651 & Inside & Cans & Powder & No & 15.375 \\
\hline FAST Standards & CPP-651 & Inside & Cans & Solid & No & 1.477 \\
\hline Fluorinel Scrap & CPP-651 & Inside & Drums & U-Zr Metal & No & 11.634 \\
\hline University Rtrs & CPP-651 & Inside & Drums & UAlx Metal & No & 0.604 \\
\hline
\end{tabular}


Table 1. INEL MIN

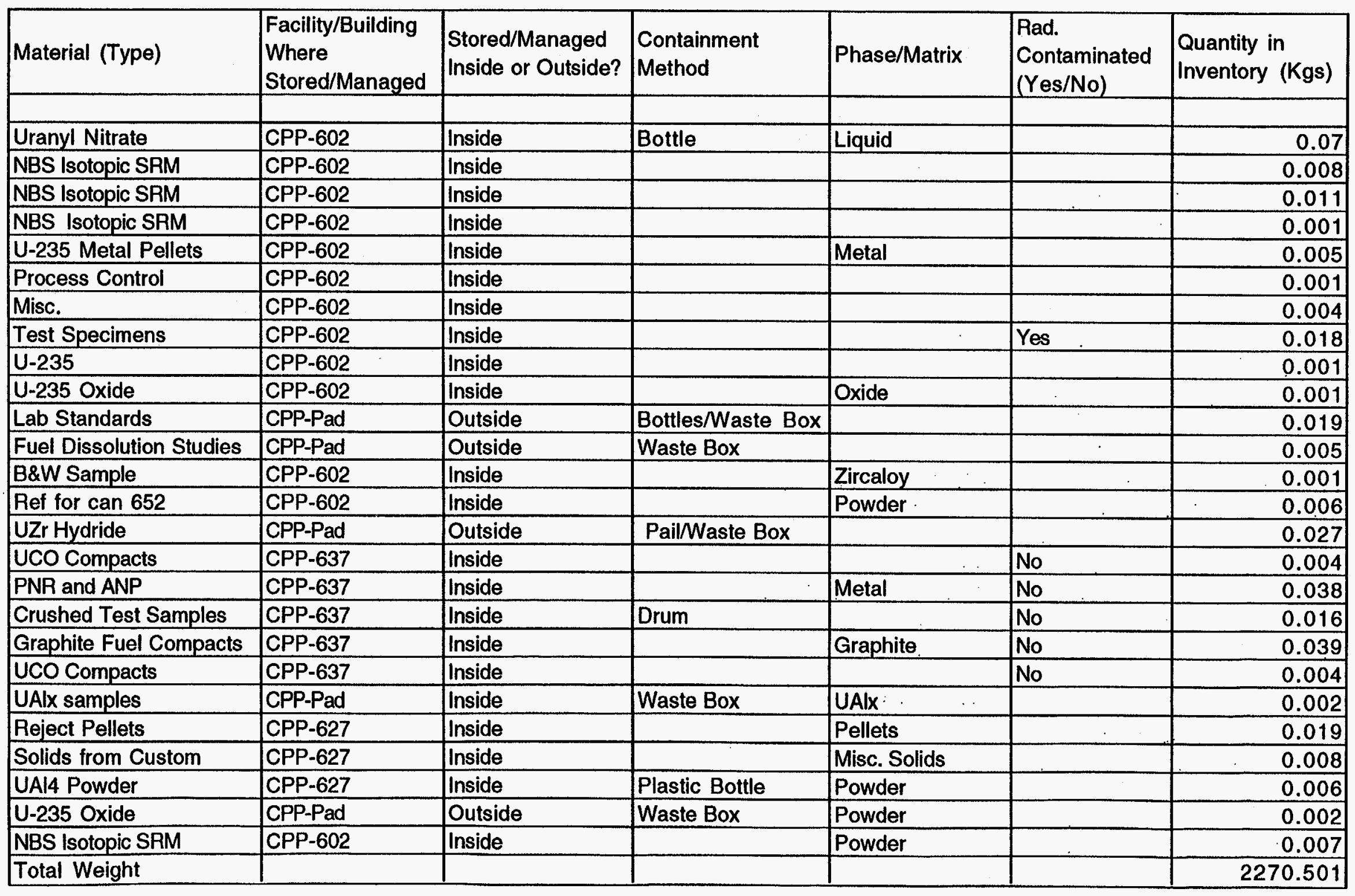




\begin{tabular}{|c|c|c|c|c|c|c|}
\hline Material (Type) & $\begin{array}{l}\text { Facility/Building } \\
\text { Where } \\
\text { Stored/Managed }\end{array}$ & $\begin{array}{l}\text { Stored/Managed } \\
\text { Inside or Outside? }\end{array}$ & $\begin{array}{l}\text { Containment } \\
\text { Method }\end{array}$ & Phase/Matrix & $\begin{array}{l}\text { Rad. } \\
\text { Contaminated } \\
\text { (Yes/No) }\end{array}$ & $\begin{array}{l}\text { Quantity in } \\
\text { Inventory (Kgs) }\end{array}$ \\
\hline & & & & & & \\
\hline ETR/GETR elements & TRA-621 & Inside & Fuel Rack & UAlx metal & No & 172.004 \\
\hline PWR Standard & TRA-621 & Inside & & & No & 0.551 \\
\hline Safeguards Standards & TRA-621 & Inside & Trays and Drums & - & No & 24.755 \\
\hline PBF Rod Standard & TRA-621 & Inside & & Powder, Capsule & No & 0.621 \\
\hline Foils & TRA-621 & Inside & Can & Metal Foils & No & 0.055 \\
\hline Pellets & TRA-621 & Inside & Can & Pellets & No & 0.284 \\
\hline Pellet Capsule, other & TRA-660 & Inside & & & & 0.011 \\
\hline Hot Frits MultiMW & TRA-632 & Inside & & & & 0.004 \\
\hline Safeguards Standards & TRA-621 & Inside & Trays & & No & 32.881 \\
\hline Safeguards Standards & TRA-621 & Inside & Trays & & No & 0.819 \\
\hline Fission Chambers & PBF-620 & Inside & & & & 0.025 \\
\hline PBF Rods & TRA-621 & Inside & Trays & & No. & 137.123 \\
\hline PBF Scrap & TRA-621 & Inside & Bottles & & No & 0.745 \\
\hline Fission Counter & PBF-620 & Inside & Canal & & & 0.001 \\
\hline MIT/LEAF plates & TRA-621 & Inside & Tray/Storage Rack & Metal Plates & No & 0.081 \\
\hline Total Weight & & & & & & 372.544 \\
\hline
\end{tabular}


Table 1. INEL MIN

\begin{tabular}{|c|c|c|c|c|c|c|}
\hline Material (Type) & $\begin{array}{l}\text { Facility/Building } \\
\text { Where } \\
\text { Stored/Managed }\end{array}$ & $\begin{array}{l}\text { Stored/Managed } \\
\text { Inside or Outside? }\end{array}$ & $\begin{array}{l}\text { Containment } \\
\text { Method }\end{array}$ & Phase/Matrix & $\begin{array}{l}\text { Rad. } \\
\text { Contaminated } \\
\text { (Yes/No) } \\
\end{array}$ & $\begin{array}{l}\text { Quantity in } \\
\text { Inventory (Kgs) }\end{array}$ \\
\hline \multicolumn{7}{|c|}{ Enriched Uranium-Off-Site } \\
\hline & & & & & & \\
\hline Foils and Tubes & U of Florida & Inside & & & Some of Each & 0.069 \\
\hline SPERT Fuel Pins & U of Florida & Inside & & UO2 Pins & & $3,041.64$ \\
\hline Fuel Plates & lowa State U & Inside & & UAlx Plates & & 0.669 \\
\hline Pathfinder & Penn State & Inside & & UO2 Pellets & & 900.677 \\
\hline & & & & & & \\
\hline Total Weight & & & & & & 3943.055 \\
\hline \multicolumn{7}{|c|}{ Normal Uranium- Non CPP Items } \\
\hline & & & & & & \\
\hline Cylindrical Piece & $604 \operatorname{Lab} 112$ & Inside & Safe & & 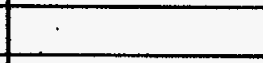 & 1 \\
\hline Total Weight & & & & 7 & & 1 \\
\hline \multicolumn{7}{|c|}{ Normal Uranlum- CPP } \\
\hline & & & & & & \\
\hline Rover Sim Ash & CPP & Inside & Waste Box & Ash Powder & & 2 \\
\hline KB NAT-10 & CPP & Inside & Waste Box & & & 13 \\
\hline AH-NAT-1,etc & CPP & Inside & Waste Box & & & 1 \\
\hline & & & & & & \\
\hline Total Weight & & & & & & 16 \\
\hline & & & - & & & \\
\hline \multicolumn{7}{|c|}{ Normal Uranlum-Off Site } \\
\hline & & & & & & \\
\hline FBBR Rods & Purdue U & Inside & & Rods & & 10,240 \\
\hline Total Weight & & & & & & 10,240 \\
\hline & & & & & & \\
\hline Grand Total & & & & & & 16,843 \\
\hline & & & & & & \\
\hline
\end{tabular}




\begin{tabular}{|l|l|l|l|l|}
\hline \multirow{3}{*}{ MIN Management Activity } & \multicolumn{3}{|c|}{ How were MIN Management Costs Estimated? } & $\begin{array}{l}\text { Annual Cost (\$K) } \\
\text { Associated with } \\
\text { Managing MIN }\end{array}$ \\
\cline { 2 - 5 } & \multicolumn{2}{|c|}{ As a Portion of Cost of An Activity } \\
\cline { 2 - 5 } & $\begin{array}{l}\text { Description of MIN } \\
\text { Management }\end{array}$ & $\begin{array}{l}\text { Cost of } \\
\text { Aanagement } \\
\text { Activity }\end{array}$ & $\begin{array}{l}\text { Estimated \% } \\
\text { Applicable to MIN }\end{array}$ & \\
\hline CPP-651 Operation & Facility Operation & $\$ 852 \mathrm{~K}$ & $100 \%$ & $\$ 852 \mathrm{~K}$ \\
\hline TRA-621 Operation & & & $100 \%$ & $\$ 160 \mathrm{~K}$ \\
\hline & Facility Operation & $\$ 160 \mathrm{~K}$ & $5 \%$ & $\$ 100 \mathrm{~K}$ \\
\hline CPP-IFSF & & & & \\
\hline Misc. Management Operations & Facility Operation & Negligible & Negligible \\
\hline
\end{tabular}

Notes:

Costs for TRA-621 include RadCon support, accountability, building checks, custodian service, security, etc.

Costs for CPP-651 vary depending on planned activities, but include surveillance and maintenance, fuel project maintenance and support, and safety analysis and operational readiness.

Costs are based on budgeted numbers for past years and vary from year to year.

Costs for IFSF are based on cost per storage position times number of positions. 
Table 3. MIN Activities

\begin{tabular}{|l|l|l|l|l|}
\hline Activity & \multicolumn{2}{|c|}{ Planned One-Time Activities } & \multicolumn{2}{|c|}{ Recurring Activities } \\
\hline & Costs, \$K & $\begin{array}{l}\text { When Could } \\
\text { Activities Occur } \\
\text { (Fiscal Year) }\end{array}$ & Costs & Frequency \\
\hline No one-time activities identified in near-term future.
\end{tabular}




\begin{tabular}{|c|c|c|c|c|}
\hline $\begin{array}{l}\text { Potential Identified } \\
\text { Disposition Option }\end{array}$ & $\begin{array}{l}\text { Amount (wt.) } \\
\text { of MIN that } \\
\text { could be } \\
\text { Dispositioned }\end{array}$ & $\begin{array}{l}\text { Specific Activities } \\
\text { Required for } \\
\text { Disposition of MIN }\end{array}$ & $\begin{array}{l}\text { Cost, by } \\
\text { Activity }\end{array}$ & $\begin{array}{l}\text { Total Cost to } \\
\text { Implement } \\
\text { Disposition Option }\end{array}$ \\
\hline $\begin{array}{l}\text { Ship PARKA Rods to } \\
Y-12\end{array}$ & 147.976 & Repackage, Transport & See Notes & $\$ 700 \mathrm{~K}$ \\
\hline $\begin{array}{l}\text { Ship ANL Scrap to Y- } \\
12\end{array}$ & 51.294 & Repackage, Transport & See Notes & $\$ 260 \mathrm{~K}$ \\
\hline $\begin{array}{l}\text { Ship LANL Graphite } \\
\text { to } Y-12\end{array}$ & 256.039 & Repackage, Transport & See Notes & $\$ 786 \mathrm{~K}$ \\
\hline $\begin{array}{l}\text { Ship UO3 Product } \\
\text { from Custom to } Y-12\end{array}$ & 25.155 & Repackage, Transport & See Notes & $\$ 125 \mathrm{~K}$ \\
\hline $\begin{array}{l}\text { Ship UO3 Product } \\
\text { from Custom to } Y-12\end{array}$ & 1.583 & Repackage, Transport & See Notes & $\$ 5 K$ \\
\hline $\begin{array}{l}\text { Package and ship } \\
\text { Metal Standard Brick }\end{array}$ & 0.831 & Repackage, Transport & See Notes & $\$ 5 K$ \\
\hline $\begin{array}{l}\text { Package and ship } \\
\text { FAST standards }\end{array}$ & 1.477 & Repackage, Transport & See Notes & $\$ 5 K$ \\
\hline $\begin{array}{l}\text { Package and ship } \\
\text { university material }\end{array}$ & 0.604 & Repackage, Transport & See Notes & $\$ 5 \mathrm{~K}$ \\
\hline $\begin{array}{l}\text { Ship ETR and GETR } \\
\text { elements to ORNL }\end{array}$ & 172.004 & Repackage, Transport & See Notes & $\$ 706 \mathrm{~K}$ \\
\hline $\begin{array}{l}\text { Ship PWR Rod } \\
\text { Standard to CSMO }\end{array}$ & 0.551 & Repackage, Transport & See Notes & $\$ 5 K$ \\
\hline $\begin{array}{l}\text { Package and ship } \\
\text { ARMF Plates }\end{array}$ & 0.13 & Repackage, Transport & See Notes & $\$ 5 K$ \\
\hline $\begin{array}{l}\text { Package and ship } \\
\text { ARMF Capsules }\end{array}$ & 0.351 & Repackage, Transport & See Notes & $\$ 5 K$ \\
\hline $\begin{array}{l}\text { Package and ship } \\
\text { safeguards standards }\end{array}$ & 24.755 & Repackage, Transport & See Notes & $\$ 120 \mathrm{~K}$ \\
\hline $\begin{array}{l}\text { Package and ship } \\
\text { safeguards standards }\end{array}$ & 0.621 & Repackage, Transport & See Notes & $\$ 5 K$ \\
\hline $\begin{array}{l}\text { Package and ship } \\
\text { MIT, LEAF Plates }\end{array}$ & 0.081 & Repackage, Transport & See Notes & $\$ 5 K$ \\
\hline $\begin{array}{l}\text { Package and ship foils } \\
\text { and tubes }\end{array}$ & 0.069 & Repackage, Transport & See Notes & $\$ 5 K$ \\
\hline $\begin{array}{l}\text { Package and ship } \\
\text { SPERT Fuel Pins }\end{array}$ & $3,041.64$ & Repackage, Transport & See Notes & NA \\
\hline $\begin{array}{l}\text { Package and ship } \\
\text { UAlx plates }\end{array}$ & 0.669 & Repackage, Transport & See Notes & $\$ 5 \mathrm{~K}$ \\
\hline $\begin{array}{l}\text { Return Pathfinder } \\
\text { assemblies to } Y-12\end{array}$ & 900.677 & Repackage, Transport & See Notes & NA \\
\hline
\end{tabular}


Table 4. Disposition Activities

\begin{tabular}{|l|r|l|l|l|}
\hline $\begin{array}{l}\text { Potential Identified } \\
\text { Disposition Option }\end{array}$ & $\begin{array}{l}\text { Amount (wt.) } \\
\text { of MIN that } \\
\text { could be } \\
\text { Dispositioned }\end{array}$ & $\begin{array}{l}\text { Specific Activities } \\
\text { Required for } \\
\text { Disposition of MIN }\end{array}$ & $\begin{array}{l}\text { Cost, by } \\
\text { Activity }\end{array}$ & $\begin{array}{l}\text { Total Cost to } \\
\text { Implement } \\
\text { Disposition Option }\end{array}$ \\
\hline $\begin{array}{l}\text { Send KB NAT to } \\
\text { Nevada Test Site }\end{array}$ & 13 & Repackage, Transport & See Notes & NA \\
\cline { 1 - 3 } $\begin{array}{l}\text { Place FBBR Rods on } \\
\text { excess list or return } \\
\text { to SRS }\end{array}$ & 10,240 & Repackage, Transport & See Notes & NA \\
\hline Total Weight & 14,880 & &
\end{tabular}

\section{Notes}

1. PARKA costs include drum return (\$2000/shipment), scale at ORNL (\$4000), support costs, and eight people to load the material ( $\$ 2880$ per drum). It is assumed that a drum can be loaded in six hours. Drum costs (\$1100 each for 136 drums) are assumed.

2. LANL costs include drums, return of drums, and eight people to load the material into the drums. Drum, drum return, and personnel costs are the same as above. Shipment requires 195 drums.

3. The costs for ETR/GETR depend on whether ETR shipping containers or $6 \mathrm{M}$ drums are used. Costs include storage racks at ORNL, packaging and loading, safeguards requirements, inspection, and other management/coordination activities.

4. Cost of Using $6 \mathrm{M}$ drums instead of ETR Shipping Containers would increase the cost by $\$ 245 \mathrm{~K}$.

5. No cost estimates exist for fuels such as those stored off-site or to be shipped to the Nevada Test Site.

6. Cost Estimates exist only for PARKA, LANL, and ETR/GETR materials, and even these costs are rough-order of magnitude costs. Other costs are estimated based on quantity of material and published costs for other materials. 
Table 5. Sale of MIN

\begin{tabular}{|c|c|c|c|c|c|}
\hline \multirow[t]{2}{*}{ Material } & \multicolumn{2}{|c|}{$\begin{array}{c}\text { Estimated Saleable Amount } \\
\text { of MIN }\end{array}$} & \multirow[t]{2}{*}{$\begin{array}{l}\text { Estimated cost to } \\
\text { prepare for sale }\end{array}$} & \multirow[t]{2}{*}{$\begin{array}{l}\text { Estimated } \\
\text { Marked } \\
\text { Price/Unit }\end{array}$} & \multirow{2}{*}{$\begin{array}{l}\text { Revenue from } \\
\text { Sale of } \\
\text { Estimated } \\
\text { Saleable } \\
\text { Amount of } \\
\text { MIN }\end{array}$} \\
\hline & $\begin{array}{l}\text { Amount } \\
\text { (Units) }\end{array}$ & $\begin{array}{l}\text { Percentage of } \\
\text { Total MIN }\end{array}$ & & & \\
\hline
\end{tabular}


Table 6. Cost Reductions

\begin{tabular}{|c|c|c|}
\hline Volume Reduction & $\begin{array}{l}\text { Annual Management Cost } \\
\text { Reduction (\%) }\end{array}$ & $\begin{array}{l}\text { Would One-Time or Recurring Cost Be } \\
\text { Incurred? (Yes/No, How Often, When) }\end{array}$ \\
\hline $25 \%$ & $0 \%$ & Yes \\
\hline $50 \%$ & $0 \%$ & Yes \\
\hline $75 \%$ & $0 \%$ & Yes \\
\hline $100 \%$ & NA & Yes \\
\hline Other & $0 \%$ & Yes \\
\hline & & \\
\hline \multicolumn{2}{|l|}{} & \\
\hline Notes: & & \\
\hline
\end{tabular}


Table 7. MIN Consolidation

\begin{tabular}{|l|l|l|}
\hline Current MIN Storage Site & Potential MIN Consolidation Site & $\begin{array}{l}\text { Potential Annual Cost } \\
\text { Savings (\$K) }\end{array}$ \\
\hline & & \\
\hline TRA-621 & CPP-651 & \\
\hline Notes & & \\
Costs to implement the move of material from TRA to CPP are estimated to be \$1.4M. \\
$\begin{array}{l}\text { Annual Cost Savings vary over the years; a NPV of \$4.612M was calculated for the } \\
\text { consolidation project. }\end{array}$
\end{tabular}


Table 8. Vulnerabilities

\begin{tabular}{|l|l|l|l|l|}
\hline Vulnerability & $\begin{array}{l}\text { Activities Required } \\
\text { to Address } \\
\text { Vulnerability }\end{array}$ & $\begin{array}{l}\text { Required } \\
\text { Frequency } \\
\text { of } \\
\text { Activities }\end{array}$ & $\begin{array}{l}\text { Up-front Costs } \\
\text { Associated } \\
\text { with New } \\
\text { Activities }\end{array}$ & $\begin{array}{l}\text { Annual Costs } \\
\text { Associated with } \\
\text { New } \\
\text { Management } \\
\text { Practices }\end{array}$ \\
\hline $\begin{array}{l}\text { Potential ignition of } \\
\text { cardboard containers } \\
\text { for PARKA fuel if high- } \\
\text { temperature accident } \\
\text { occurred }\end{array}$ & $\begin{array}{l}\text { Remove fuel and } \\
\text { transfer to Y-12 }\end{array}$ & Once & $\$ 700 \mathrm{~K}$ & None \\
\hline Notes & & & \\
See Table 4 concerning items included in cost estimate.
\end{tabular}

